\title{
O urbanismo de Saturnino de Brito e as ressonâncias provocadas
}

\author{
Daniel Tochetto \\ Arquiteto e Urbanista, mestre pelo Programa de Pós-graduação \\ em Planejamento Urbano e Regional - PROPUR, da Universidade \\ Federal do Rio Grande do Sul, arquiteto e urbanista do Instituto de \\ Planejamento de Santa Maria, Rua Venâncio Aires, 2035/8 Andar, \\ Centro, RS, CEP 97010-005, (55)3219-0104, danieltoch@gmail.com

\section{Célia Ferraz} \\ Arquiteta e Urbanista, professora doutora do Programa de \\ Pós-graduação em Planejamento Urbano e Regional - PROPUR, \\ da Universidade Federal do Rio Grande do Sul, Avenida Paulo \\ Gama, 110, Secretaria de Comunicação Social, $8^{\circ}$ andar, Reitoria, \\ Farroupilha, Porto Alegre, RS, CEP 90040-060, (51) 3308-6000 \\ cefsouza@terra.com.br
}

\section{Resumo}

Na elaboração de projetos de saneamento para as cidades brasileiras, o engenheiro Francisco Saturnino Rodrigues de Brito defendeu a necessidade de desenvolver conjuntamente aspectos pertinentes ao campo do urbanismo. O entendimento de Brito sobre como pensar a cidade foi detalhado e desenvolvido na época em que trabalhou para a Comissão de Saneamento de São Paulo, no contexto de sua Usina de Santos em 1905-10, e Notas sobre a traça sanitária das Vilas (1916). A análise dessas duas obras, juntamente com a discussão e os problemas que ocorreram em Santos, constituem o objetivo central deste trabalho.

Palavras-chave: urbanismo sanitarista, Saturnino de Brito, Europa, Brasil.

1 Na época chamado de plano de extensão, melhoramentos ou embelezamento. engenheiro Francisco Saturnino Rodrigues de Brito, carioca de nascimento, formado pela Escola Politécnica do Rio de Janeiro, em 1886, desde cedo dedicou-se ao sanitarismo e se tornou o maior expoente no país, até 1924, quando faleceu em Pelotas-RS, enquanto realizava o plano dessa cidade. Destaca-se, na sua atuação, a posição de sempre ter defendido a necessidade da elaboração de um plano para a cidade, antes mesmo de projetar as redes de infraestrutura e saneamento, já que essas deveriam crescer com a cidade. Se essa não tivesse um plano ${ }^{1}$, então teria que fazê-lo. Brito entendia o plano como um meio de assegurar um desenvolvimento harmônico das cidades e de redefinir o conjunto de sua estrutura (SOUZA, 2010). Esse procedimento o levou a estudar mais profundamente a cidade, conhecer autores desse campo, discutir com os mesmos, escrever sobre o assunto, participar de vários congressos para então elaborar os planos, o que fez para diversas cidades brasileiras. Brito propôs em média vinte e oito planos pelo Brasil, entre eles o de Santos, chamado de Planta de Santos, um de seus primeiros trabalhos, que suscitou uma grande discussão com a Câmara Municipal, da qual permite pinçar claramente suas ideias. Dos seus textos, teve grande repercussão o escrito Notes sur le tracé sanitaire des villes, de 1916, que enviou à França e mereceu um prêmio da Association Générale des Hygienistes et Techniciens Municipaux. O objetivo deste artigo é mostrar como as ideias urbanísticas de Brito circularam pelo Brasil e fora dele, focando a análise na Planta de Santos, no texto enviado para França e nas indicações para higiene das habitações que escreveu em 1903, que complementa o assunto. 


\section{A Planta de Santos e sua repercussão}

2 O filho de Brito (1944c, p. 5) resume os motivos que levaram a planta a não ser aprovada: "Almeida Morais, porém, faleceu antes de se concluir o projeto de urbanização e seus sucessores na Prefeitura e na Câmara Municipal estavam longe de possuir o mesmo espírito superior. Ao contrário, achavam-se dominados pelos seguintes imperativos, que os conduziam a não aceitar a planta de previsão organizada: $\left.1 .{ }^{\circ}\right)$ muitos dos 'grandes eleitores' da situação política municipal eram também grandes proprietários de terra e desejavam explorá-las a seu talento; 2.) aos espíritos de arraial da maioria deles, a não aceitação da planta da cidade elaborada por uma repartição do estado, trazia a sensação de um excelente 'exercício' da 'autonomia municipal'; 3.') o engenheiro da municipalidade, então jovem inexperiente, pensava que Ihe seria fácil apresentar 'plano próprio', com numerosos traçados de 'ruas em curvas', com 'parques', conforme leituras apressadas que fizera de assunto novo na época e que só poderia ser bem solucionado com maior lastro de senso prático.

3 Nos relatórios dos trabalhos de 1905-6, 1907, 1908 e 1909, Brito (1944a) descreveu muitos dos problemas e apresentou soluções conforme as medidas adotadas na Europa e relatos de experiências de diversos profissionais estrangeiros. Nessa ocasião, 0 engenheiro também publicou diversos artigos no Brasil e na França.

4 A "Lei, denominada Estatuto da Cidade, estabelece normas de ordem pública e interesse social que regulam o uso da propriedade urbana em prol do bem coletivo, da segurança e do bem-estar dos cidadãos, bem como do equilíbrio ambiental" (BRASIL, Lei $n^{\circ}$ 10257/2001).

5 "A pesquisa foi conduzida em 1997/1998 na PUCCampinas, financiada pela Fundação de Amparo à Pesquisa do Estado de São Paulo e pelo Lincoln Institute of Land Policy" (ROLNIK, 1999, p. 76).
O Governo do Estado, através da Comissão de Saneamento do Estado de São Paulo, dirigida por Saturnino de Brito, estava encarregado do saneamento de Santos. Mas, segundo Brito, para fazer e implantar esse serviço, era preciso um plano municipal com a previsão do crescimento da cidade, tanto nas áreas já ocupadas como nas ainda ociosas, o que não exista. A intenção da Comissão não era elaborar um plano para Santos, mas, uma vez que esse não estava estabelecido, não havia outra opção a não ser traçar um plano geral e definir uma legislação para garantir sua implantação para poder então projetar o saneamento (BRITO, 1944C).

A tarefa da atualidade consistirá essencialmente, como se depreende do que temos dito, em levantar as plantas das cidades existentes e dos terrenos adjacentes, para estudar os melhoramentos da parte construída e os planos de saneamento e de expansão; este trabalho metódico deve ser regulamentado por lei e exigido também para os pequenos núcleos populosos que progridem (BRITO, 1944c, p. 16).

Não bastava simplesmente elaborar um plano para a cidade, era preciso também que esse fosse declarado de utilidade pública e possuísse leis que garantissem a sua implantação. Assim, Brito, com o auxílio de dois arquitetos, Bruno Simões Magro e Nicolao Spagnolo, de 1905 a 1910, elaborou um plano completo, conhecido como a Planta de Santos. Quando finalizado, foi conduzido à Câmara em nome da Comissão de Saneamento para aprovação.

A Câmara não o aprovou², alegando haver influência de estranhos, mas dele pinçou o que julgava apropriado, de forma a tomar decisões pontuais e baseadas em interesses particulares e específicos, o que criou uma série de desentendimentos. Um dos argumentos da Câmara para essa postura foi de que a cidade já possuía um plano próprio e estava tomando as decisões conforme eram necessárias. Em resposta, Brito (1944c, p. 88) alegou que esse plano próprio não existia e disse mais:

[...] não é admissível que cada prefeito tenha desses "planos incubados", de laboriosa gestação e partos sucessivos, em tempos indeterminados. O plano deve ser estudado com um caráter geral e harmônico; a execução é que virá progressivamente, em diversas administrações (BRITO, 1944c, p. 68).

A concepção de Brito sobre a elaboração e a implantação do plano é justamente a mesma que se tenta seguir ainda hoje, porém, muitas vezes, repete-se a mesma situação descrita em Santos: cada prefeito quer elaborar o seu plano com suas ideias.

A Planta de Santos, juntamente com os instrumentos necessários para garantir a sua implantação e guiar o crescimento urbano, mostrou a aplicação do conhecimento que Brito tinha no campo do urbanismo ${ }^{3}$. Conhecimento esse obtido a partir dos encontros e de autores estrangeiros, que the fizeram sentir a necessidade e a obrigação de pensar no futuro das cidades mediante um plano, a fim de evitar reincidências nos mesmos erros e deixar o futuro entregue ao acaso, "[...] isto é, dependente do capricho e da ignorância dos proprietários e das administrações locais" (BRITO, 1944c, p. 16). Ao elaborar e/ou indicar o conjunto de regras necessárias para isso, pois elas não existiam ou eram incipientes demais no Brasil, Brito desenvolveu assuntos que vieram a fazer parte dos planos diretores e dos instrumentos urbanísticos da Lei Federal conhecida como Estatuto da Cidade ${ }^{4}$, aprovada em 2001. Um desses exemplos é a contribuição de melhoria, imposto a ser cobrado em vias que recebem melhora na infraestrutura, de modo a valorizar os lotes no entorno, como seria o caso com a implantação da avenida canal. Esse imposto já era indicado pelo engenheiro desde 1902 (BRITO, 1944C). Segundo pesquisa Raquel Rolnik $^{5}$ (1999, p. 76), nas cidades paulistas com mais de 20.000 habitantes, "[...] os instrumentos específicos mais recorrentes são: Contribuição de Melhoria, encontrada em 53,39\% dos municípios pesquisados, e Legislação Especial de Habitação de Interesse Social, em 43,22\% [...]".

A função e o modo de implantar o traçado viário - a avenida parque e a avenida canal, ambas largas e arborizadas, como os bulevares de Paris - e a implantação dos espaços públicos - tanto os pequenos jardins como os ao longo das vias, seguidos de preocupações técnicas e estéticas são características marcantes do trabalho de Brito. Esses tiveram enorme repercussão na cidade e no material que enviou para publicação na França. Se forem observadas várias das plantas elaboradas 
pelo engenheiro, os traçados e as áreas verdes possibilitam a rápida identificação do autor.

A avenida canal e a avenida parque, esta com um parque linear com equipamentos urbanos e aquela com um canal, tornaram-se elementos de grande utilidade e beleza para a cidade, como também elementos estruturadores do sistema viário. A avenida com o canal a céu aberto possibilitou a drenagem das superfícies, onde passou a ser possível prever áreas para expansão urbana e resolver, juntamente, os problemas de acesso. Muitas das características dos bulevares franceses estiveram presentes nos projetos de Brito, como a via larga e arborizada, mas com uma diferença, o canal d'água, que levou o autor Monteiro de Andrade (1992), que já realizou diversos estudos sobre a atuação de Brito, a denominar a via de bulevar sanitarista (Figura 1). Esses eram avenidas de 30 a $35 \mathrm{~m}$ de largura com um canal ao centro margeado por vegetação.

Os dois tipos de avenidas propostas por Brito, além das funções de facilitar o trânsito, o escoamento das águas e o conforto, deveriam ter funções estéticas e sociais. No parque da avenida, Brito indicou a implantação de equipamentos urbanos, como escolas, bosques e quadras de esportes (Figura 2). Como ocorrera na capital francesa, com as reformas de Haussmann, o espaço público passara a ser o local de encontro e de uso de todas as classes.

A nova composição urbana proposta mudou a percepção que a população tinha e vivenciava na cidade, de forma análoga ao que ocorrera na Paris de Haussmann segundo análise de Marshall Berman (2007). No Brasil, conforme Andrade (1992, p.142), "o passeio pelos canais e avenidas possibilitará, em uma deambulação pinturesca, o contato poético com uma paisagem sob controle - natureza submissa mas que não perde a beleza dos organismos em harmonia". Esse uso e domesticação da natureza no meio urbano em larga escala foram os mesmos princípios utilizados por Jean Charles Adolphe Alphand ${ }^{6}$, em Paris, conforme mostra Picon (2001). A preocupação de Brito em utilizar a vegetação era proporcionar espaços confortáveis nas ruas e nos espaços públicos de lazer, inspirando-se também nos parques franceses, Bois de Vincenne e Bois de Boulogne. Nesse ponto, Brito fez referência a esses parques e foi mais além na proposta, indicou a utilização de eucaliptos como "filtro balsâmico para os ventos" e dreno vertical, podendo futuramente a madeira ser uma fonte de renda ao município.

As longas ruas retas, conforme princípios estéticos que trouxe de Camilo Sitte, arquiteto vienense que escreveu o livro Der Städtebau nach seinen künstlerischen Grundsätzen em 1889, foram evitadas com pequenas praças e jardins em cruzamentos ou extremidades de avenidas. Alguns desses espaços, que poderiam ser implantados em maior quantidade caso o poder municipal desejasse, foram utilizados para instalação de equipamentos sanitários, como estações elevatórias, usinas de tratamento de esgotos e banheiros públicos. Em Santos, a área verde prevista que teve mais destaque foi o parque da avenida beira-mar, a Orla de Santos, utilizada para instalação de equipamentos de uso público, como campos de esporte (Figura 3).

A preocupação se estendia também à estética da cidade e às sensações proporcionadas pelos espaços e pelo traçado viário. Referente a isso, Brito comentou sobre o desalinhamento entre os prédios e a necessidade de tirar proveito da topografia, em termos práticos e estéticos. Com o objetivo de sanear o espaço, as propostas de Brito foram da escala urbana à local, alterando a implantação das edificações no lote e a tipologia para uma com recuos no alinhamento e nas laterais. Junto a isso, surgiu também a viela sanitária e/ou a rua particular. Para a implantação dessa, Brito indicou uma legislação que obrigasse as edificações a afastar determinada distância do eixo traçado, para, no futuro, ao abrir a via, só se expropriar terrenos e muros. Essa via passaria pelo meio da quadra, nos fundos dos lotes, e facilitaria a implantação e manutenção da rede d'água e esgotos em quarteirões insalubres.

A salubridade e a estética na cidade seriam asseguradas, de modo geral, por uma relação estabelecida por Brito entre a largura das vias, recuos e altura das edificações: ruas com largura mínima de $7 \mathrm{~m}$ quando os prédios fossem construídos, pelo menos, a 2,5m para dentro do alinhamento, ficando à frente uma varanda, alpendre, jardim de largura igual ou superior a 2,5m; quando os prédios ficassem no alinhamento da rua, essa teria largura igual ou superior a 12m; em qualquer dos casos, a parte central poderia ter a largura mínima de $5 \mathrm{~m}$, sendo o excedente destinado a passeios laterais. Nenhuma construção poderia ter altura superior à largura da rua (BRITO, 1944b). 

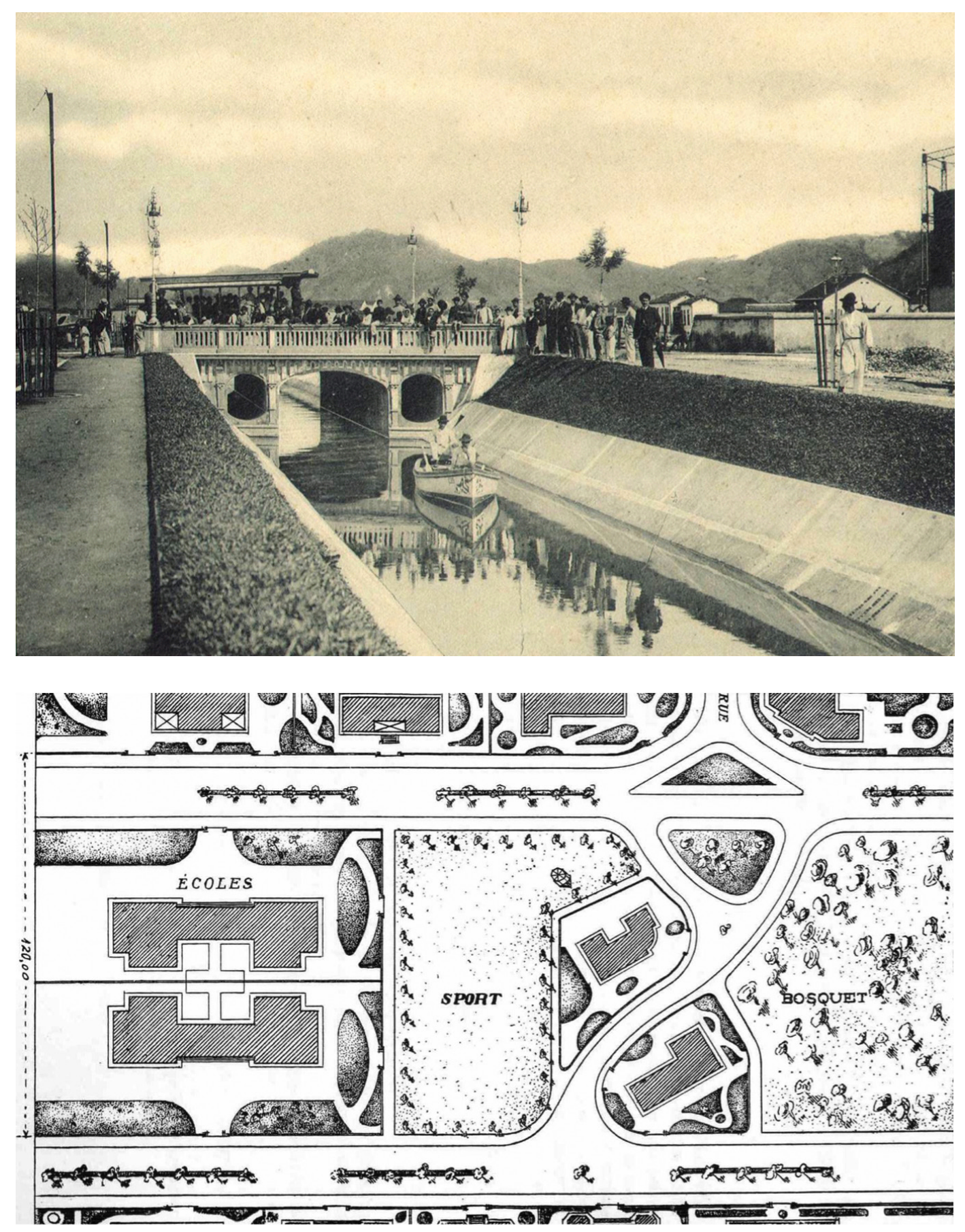

Figura 1 (topo): Ponte na Av. Cons ${ }^{\circ}$ Nebias em concreto armado. Fonte: Brito (1943b).

Figura 2: Detalhe da avenida parque com equipamentos urbanos em meio ao espaço verde, onde há escolas, quadra de esporte, bosque e mais duas edificações com uso não identificado pelo autor. Fonte: Brito (1944b). 


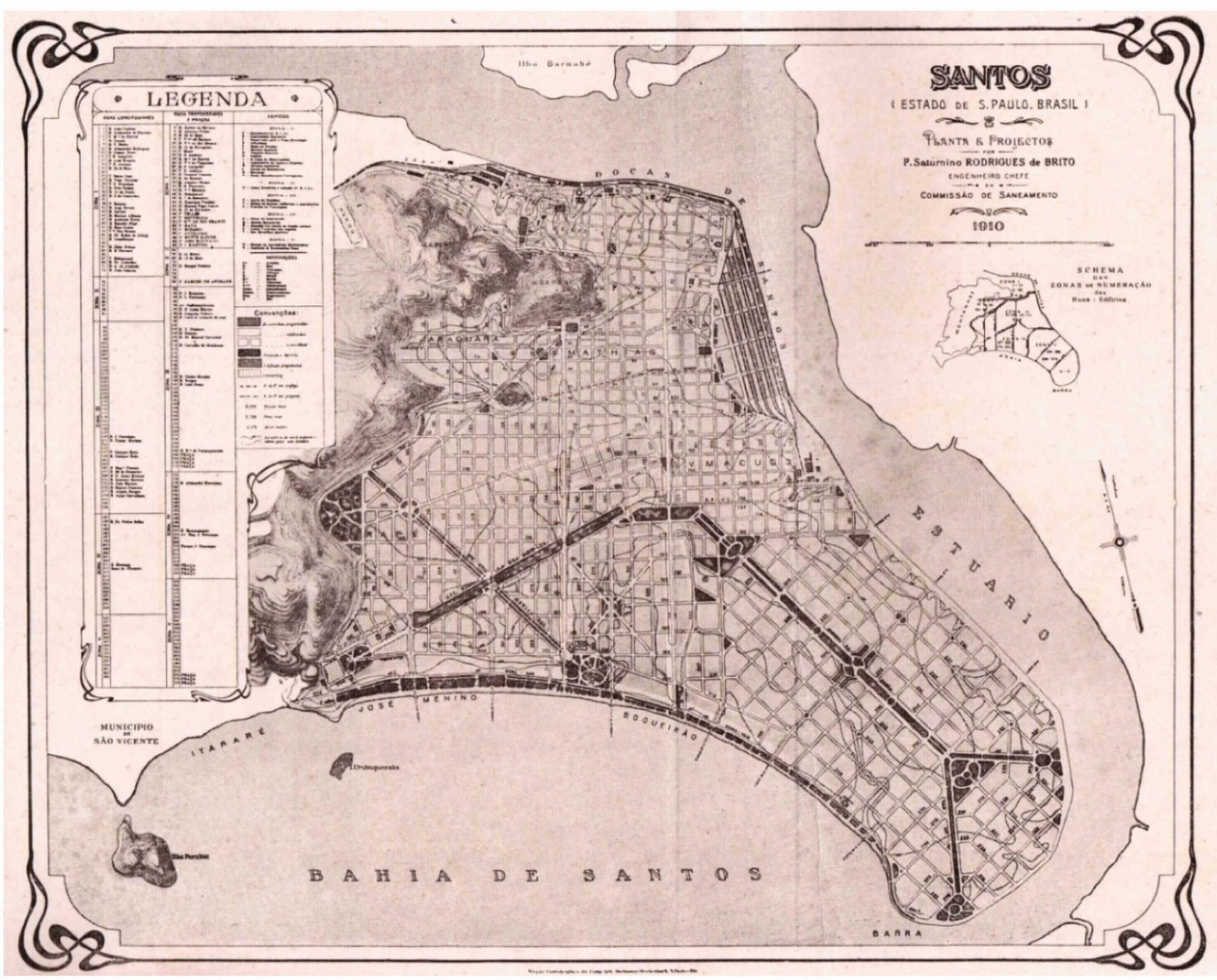

Figura 3: Planta de Santos. A via que se destaca atravessando a região central e em maior largura é a Avenida Parque. Outro espaço público importante previsto foram os jardins ao longo da orla ao sul, também configurando um parque linear Também é possível notar as praças e espaços verdes propostos distribuídos pela cidade. Fonte: Brito (1944a).
O trabalho da Comissão de Saneamento trouxe grandes transformações para Santos, que se tornou mais uma referência além do Rio de Janeiro de Pereira Passos na Primeira República. Surgia uma nova e moderna cidade, baseada nos moldes das europeias. A avenida canal, além de suas funções, virou um novo espaço urbano de encontro. No campo do urbanismo, diversos profissionais puderam ver essas transformações de perto e colaborar com o desenvolvimento das ideias de Brito. Conforme avalia Andrade (1992, p. 142) a atuação de Brito

[...] implicou não apenas a aplicação, pioneira no País, dos princípios da urbanística nascente, como o zoneamento de atividades, o plano de conjunto, etc. mas, sobretudo, promoveu uma efetiva transformação da imagem da cidade de traços coloniais, causando um impacto sem precedentes na vida urbana local [...].

Mesmo a Planta de Santos não tendo sido realizada por completo, as obras executadas e as ideias presentes nela foram de extrema importância para o campo do urbanismo no Brasil e na Europa. Conforme avalia Andrade (1992, p. 144),

[...] não apenas temos a construção de uma cidade moderna, mas também a aplicação de princípios urbanísticos revolucionários para a época, onde o passado colonial da cidade desaparece em nome de um futuro marcado pela higiene e o progresso, que influenciará decisivamente no desenvolvimento do planejamento urbano no Brasil. 


\section{Repercussões}

Um dos exemplares da Planta de Santos foi enviado, por Saturnino de Brito, ao arquiteto francês Joseph Antoine Bouvard - sucessor de Alphand no cargo de Diretor de Obras, Serviço de Arquitetura, Passeios e Plantações da Cidade de Paris - que fez comentários positivos em relação ao trabalho e reforçou que toda cidade, de pequena importância que fosse, deveria unir esforços e elaborar um plano, para evitar continuar agindo dia a dia, no impulso do momento ou por influências passageiras (BRITO, 1944c). As "influências passageiras" a que Bouvard e Brito se referiram eram justamente o que estava ocorrendo em Santos, decisões tomadas segundo interesses políticos e de forma pontual. Bouvard tinha a mesma opinião que outros profissionais também citados por Brito ${ }^{7}$ e estava de acordo com que a Comissão tentou aplicar em Santos, com a planta e a legislação proposta.

7 Brouardel et Mosny, Descroix, Strauss e Fillassier, Duclaux, Gautrez, Siegfried citam as legislações de outros países e são por Brito citados.

8 Na época, Ingénieur en Chef des Ponts et Chaussées e Directeur des Travaux de la Ville de Nancy.

9 Secretário geral tesoureiro da Associação.
Nesse sentido, Bouvard, Brito e outros profissionais já defendiam o que ainda hoje é dito e se tenta praticar: o planejamento da cidade como um processo contínuo e desenvolvido por um corpo técnico permanente, independente das administrações municipais, principalmente do mandato dos prefeitos e dos vínculos políticos. Há uma vasta discussão desenvolvida por Brito com base em leis e autores estrangeiros no que diz respeito às leis existentes, às necessárias e à competência dos prefeitos, juntamente com sua posição contrária à realização do planejamento do municípios por órgãos ligados diretamente à administração municipal. Brito, através de exemplos apresentados nos congressos dos quais participava ou tinha conhecimento no exterior, mostrava a viabilidade e importância das ideias e legislações que defendia. Um de seus relatos apresentados foi o referente ao Congrés International pour la Protection des Paysages, em 1909, que reforça a sua posição, pois, no evento,

[...] contem várias opiniões confirmativas do que temos dito quanto à necessidade dos planos geraise da legislação que deve garantir a sua execução. Neste sentido pronunciou-se George Montenach, deputado do Grand Conceil Du Canton de Fribourg, elogiando a iniciativa do deputado Beauquier, na França. São devidamente responsabilizadas, neste Congresso, as administrações politiqueiras, como a de Santos, "qui ont besoin de flatter leur clientèle électorale".
O Dr. Fuchs disse que na Alemanha a questão está praticamente resolvida: as cidades obedecem aos planos de expansão: "estes poderiam ser melhores, mas são certamente melhores que nada". Um outro autor diz que depois da lei de 1875, impondo às cidades um plano de extensão, a lei Adickes adotada pelo Landtag prussiano em 1902, "Ihes dá as mais felizes facilidades para aplicá-la:" a expropriação é feita por utilidade pública; projetam-se as ruas, squares, etc. [...] (BRITO, 1944c, p. 216).

Com base em legislações aplicadas no exterior, como na Alemanha, em que os conselhos municipais deviam apresentar ao ministro das obras públicas um plano de expansão das suas cidades, e na intenção de combater justamente o que ocorreu em Santos, Brito (1944c, p. 167) justificou que propôs "[...] fazer o que se tem proposto fazer e se tem feito em outros países, a saber, modificar a legislação de modo a atender às necessidades criadas pela vida social na atualidade, quanto à salubridade e quanto à expansão das cidades". Junto ele salientou a importância dos planos para as cidades, independente do porte. A difusão dessa postura levou-o a ser um dos principais colaboradores da circulação de ideias que estavam sendo debatidas e aplicadas no exterior, no Brasil, sendo que muitas delas estão presentes, ainda hoje, em nossas legislações.

\section{O livro Notes sur le Trace Sanitaire des Villes}

Saturnino de Brito enviou um outro exemplar da Planta de Santos ao engenheiro e médico francês Dr. Edm. Imbeaux ${ }^{8}$. Esse fez comentários sobre os serviços de saneamento em Santos, em seu livro publicado em 1911, citando Brito, e enviou um exemplar para o engenheiro que estava em Recife. 0 Secretário da Association Générale des Hygienistes et Techniciens Municipaux da França, C. H. Regnard ${ }^{9}$, também leu o livro a Planta de Santos e fez boas considerações a respeito. A associação estava muito preocupada com a reconstrução dos locais destruídos pela Primeira Guerra e procurava seguir métodos de higiene e racionalidade, juntamente com uma estética exigente. Por esse motivo, para divulgar essas ideias que eram novas na França, a associação promoveria a Exposition de la Cité Reconstituée, em Maio-Julho de 1916. Assim, o livro a Planta de Santos seria interessante para a exposição e, se desejasse, 
Brito poderia enviar algum outro trabalho sobre o assunto (REGNARD apud BRITO, 1944b). Foi então que Brito desenvolveu o seu livro Notes sur le tracé sanitaire des Villes. Na avaliação desse trabalho, a comissão julgadora do evento considerou-o digno de uma recompensa e o vice-presidente da seção parisiense da associação e professor na École Centrale, M. J. Bergeron, escreveu a apresentação do livro na revista Technique Sanitaire (out/1916, p. 266) em que se destaca o trecho:

10 Tradução nossa.

11 Tradução nossa

12 Versão traduzida por Camille Martin publicada em 1902, do original Der Städtebau nach seinen künstlerischen Grundsätzen, 1889.

13 A tradução do termo seria plano de conjunto, mas será referenciado somente como plano geral ou simplesmente plano, palavra utilizada por Brito nas suas publicações em português.

14 SITTE, Camillo. L'Art de Bâtir les Villes - notes et réflexions d'un architect, Libraire Renouard, H. Laurens Éditeur, Paris, 1918 (1902). O livro de Sitte possui uma versão em português com o título de A construção das cidades segundo seus princípios estéticos (1992).

15 Mesmo assim, segundo Albert Peets (apud ANDRADE, 1994, p. 6), "a tradução de Martin talvez tenha sido indispensável. Assim, ao invés de questioná-la, em nome de uma tradução fiel às formulações originais de Sitte em alemão, preferimos ler a tradução de Martin no que vale por sua invenção, sua re-criação de um outro texto, portanto, também, de uma outra teoria urbanística".

16 Dos quais destaca-se $\mathrm{M}$. Ch. Dupuy, vice-presidente da Société Centrale des Architect à Paris.

17 Dos quais destaca-se M. Frank Koester, de New York, autor do livro American City Planning. ao escrever esse trabalho, o Sr. Brito prestou um verdadeiro serviço a todos os seus colegas, primeiramente os beneficiando com sua experiência e após mostrando que através da competência e do conhecimento é possível se impor... mesmo quando se faz o bem ${ }^{10}$.

A revista francesa intitulada La Technique Sanitaire et Municipale era uma publicação da Association Générale des Hygienistes et Techniciens Municipaux da França, Inglaterra, Tunísia, Bélgica, Suíça e GrãoDucado de Luxemburgo. Na revista, Brito consta como um membre d'honneur da associação. Os exemplares eram distribuídos em diversos países, conforme consta uma lista das administrações municipais membros da associação, inclusive algumas do Brasil, como Pelotas, Porto Alegre, Recife, Rio de Janeiro, Santos e São Paulo. Então, o livro de Brito teve uma ampla divulgação. O prefácio desse foi escrito por Edm. Imbeaux, que comentou a importância do livro, a situação insalubre das cidades no Brasil e a elevada quantidade de mortes devido a epidemias no Rio de Janeiro e em Santos, no ano de 1899:

é uma importante contribuição que este amigo do exterior nos traz hoje sobre o traçado mais adequado para as cidades e suas ruas: aos resultados de sua experiência de crescimento das cidades da América do Sul, ele junta os relatórios e discussões do Congrès d'Ingénieurs de San Francisco (1915). Não pode ser melhor documentado ${ }^{11}$ (IMBEAUX apud BRITO, 1944b, p. 26).

O livro, até hoje, sem nenhuma versão traduzida para o português, é a compilação das ideias presentes nos projetos de Brito, em que trabalhou com a dimensão estética, tecnológica e territorial da cidade, e se divide em sete partes: 1. Préface; 2. Avant-propos; 3. Chapitre I - L'art de bâtir lês Villes, les villes enciennes et les villes modernes, les plans d'ensemble; 4 .
Chapitre II - Compétence administrative et technique pour organiser et exécuter les plans d'ensemble, législation nécessaire; 5 . Chapitre III - Notes sur le tracé sanitaire des villes; 6 . Conclusions; 7. Annexe. No título do primeiro capítulo, L'art de bâtir lês villes, les villes enciennes et les villes modernes, les plans d'ensemble, já fica clara a ligação das ideias do autor com as de Camillo Sitte, através do livro L'art de bâtir les Villes - notes et réflexions $d^{\prime}$ um architect ${ }^{12}$. Pela comparação dos títulos, é possível perceber a semelhança dos assuntos que foram abordados. Este falou sobre a arte de construir as cidades, em que as cidades antigas eram construídas segundo princípios artísticos, perdidos após o Barroco. Aquele, fazendo referência a Sitte, abordou o mesmo assunto, o pitoresco e a preocupação com a estética, desenvolvendo-os no decorrer do livro ao mesmo tempo em que apresentou o modo sanitário, técnico, de traçar as cidades e salientou a importância de um plano, no caso denominado de plan d'ensemble ${ }^{13}$.

Nos projetos que realizou para as cidades, Brito chamou atenção da importância dos predicados estéticos através da ideia de pitoresco que trouxe de Sitte. Em janeiro de 1905, o "amigo e colega" Joaquim de Castro Fonseca presenteou Brito com a versão francesa do livro de Camillo Sitte com a seguinte dedicatória: "possa esta pequena lembrança trazer-Ihe sempre à idéia a unidade de vistas em que nos achamos sobre que de verdadeiramente bom e inquestionavelmente belo se poderá fazer em proveito deste nosso 'maltratado torrão' (o Rio de Janeiro)" (BRITO, 1944c, p. 162). O livro de Sitte mais conhecido na época foi a versão traduzida para o francês pelo arquiteto suíço Camille Martin, publicada em $1902^{14}$. Essa versão foi bem questionada por Collins (2006) e Andrade (1994), pois possuía muitas omissões e divergências, como a retirada de um capítulo e a inserção de outro, a substituição de referências ao barroco por exemplos medievais e de imagens de cidades alemãs por francesas ou belgas ${ }^{15}$.

No decorrer do livro, Brito citou diversos autores europeus ${ }^{16}$ e americanos ${ }^{17}$, publicações e congressos que ocorriam na Europa sobre o saneamento e a necessidade de planejar as cidades, sendo os mais significativos: Premier Congrès Internacional et Exposicion comparée des Villes (1913); Royal Sanitary Institute Congress de Blackpool; Revue d'Hygiène Municipale; Guide pratique pour la Reconstruction, 
18 Escrito por Eug. Couturaud.

19 Os dois últimos, baseados nos princípios de Ebenezer Howard e de Camillo Sitte, planejaram a cidade jardim de Letchworth.

20 Andrade em suas publicações utiliza o termo pinturescos, fazendo referência à pintura. Mas o termo mais utilizado e aceito atualmente, como Brito já escrevia, é pitoresco.
I'Extension, l'Aménagement et l'Embellissement des Villes $^{18}$. É possível perceber a proximidade que o autor tinha com os acontecimentos no campo do urbanismo no exterior, trazendo e implantando muitas ideias de diversos locais no Brasil através de seus trabalhos. Do Congresso Internacional de Higiene e de Demografia em Washington (1912), Brito (1944c, p. 214) se referiu às palavras de George Mc. Crac. de Edimburg: "'o custo de town planning não será proibitivo para qualquer municipalidade bem governada' (só as mal governadas inventam pretextos para não ter os seus planos gerais executados)" . Essa citação foi utilizada para mostrar o descaso da municipalidade de Santos em relação ao trabalho prestado pelo Estado na elaboração da planta, preocupado com a higiene pública e o progresso da cidade.

O crescimento da cidade não poderia ocorrer sem nenhum regramento, isto é, deveria ser guiado por um plano do ponto de vista técnico e artístico, defendia Brito. Quanto a esses dois preceitos: referente ao técnico estava o saneamento da cidade, escoamento das águas, ocupação do solo para garantir iluminação e ventilação das edificações e o funcionamento da cidade moderna; referente ao artístico, aliado ao técnico, uma vez que para o escoamento natural das águas era necessário seguir a topografia, o traçado da cidade, adequado ao perfil natural do terreno, seria dotado de qualidades pitorescas, retomando o sentimento artístico. Esse, que, segundo Sitte, não estava mais presente na construção das cidades.

A obra de Camillo Sitte foi um marco nas teorias urbanísticas do final do século XIX. No início do século seguinte, ela foi muito valorizada por profissionais como Brito, Barry Parker e Raymond Unwin ${ }^{19}$, mas também muito criticada, conforme Le Corbusier escreve em seu livro Urbanisme (1925). Sitte também foi um dos primeiros a se preocupar com a preservação das cidades históricas e a questionar os longos eixos de um traçado ortogonal e as destruições promovidas pelas grandes reformas urbanas, postura também adotada por Brito.

Deixar a construção da cidade ao acaso provocaria a desordem, sem plano e sem regras, cada um construiria diferente de seu vizinho e por conveniência. Sitte e Brito tinham preocupações em comum, como a construção desordenada da cidade, mas Sitte estava mais preocupado com o que se deveria aprender com o passado, enquanto Brito, embora considerasse o passado também importante, defendeu a necessidade de ordenar o crescimento se preocupando com o futuro. Desse modo, Sitte estava mais voltado à preservação da cidade e Brito, principalmente, em planejá-la, pensar no seu futuro, considerando a preservação do existente e preocupado com os predicados estéticos.

Em seus projetos, Brito procurou intervir o mínimo possível no traçado urbano existente. De modo geral, suas intervenções eram as aberturas de vielas sanitárias, avenida canal ao longo dos cursos d'água, implantação de espaços públicos e valorização de visuais pitorescas ${ }^{20}$.

Um suposto defeito de plano, um acidente topográfico, se transformam em belezas quando o profissional competente as sabe criar ou expor à vista dos transeuntes. Os ilustres Snrs. Camillo Sitte, Vierendeel, e recentemente o Snr. Bouvard (arquiteto de Paris que passou pelo Rio de Janeiro para ir reformar Buenos Aires), dão aproveitáveis lições sobre os traçados dos novos arrabaldes e melhoramentos e embelezamentos [...] (BRITO, 1943b, p. 51).

E com esses preceitos foi concebida a Planta de Santos:

sobre a planta que encontrei (sem me preocupar com as suas imperfeições, resultantes do processo de levantamento), projetei a expansão da cidade, com pequenos jardins, sem a preocupação das extensas ruas retas, que formam um xadrez nas plantas chamadas geométricas; são os patês de maisons. na expressão de C. Sitte (BRITO, 1943b, p. 51).

A rua reta era muito útil, ainda mais em terrenos planos, mas essa tinha alguns inconvenientes. Como solução para resolvê-los, Brito indicou a implantação de áreas verdes ao longo das vias e pequenas mudanças de direção, medidas suficientes para evitar o desconforto, como Sitte descreveu, de ruas extensas que parecem intermináveis. Um dos exemplos apresentados por Brito foi a avenida parque na Cidade de Santos, em que a via era reta, mas foram utilizados diversos elementos ao longo dela para evitar o desconforto.

O traçado da cidade moderna, segundo Brito (1944b), deveria ser elaborado conforme suas necessidades, não copiando o traçado das cidades antigas, mas inspirando-se nelas. Nesse sentido, Brito desenvolveu novas ideias referentes ao traçado 
urbano e definiu que a necessidade era a circulação, abrir ruas, criar avenidas, elementos incompatíveis com os planos irregulares das cidades antigas. As necessidades da vida moderna não poderiam mais se adaptar aos traçados irregulares da maioria das cidades antigas, pelo menos, em alguns de seus bairros. Algumas modificações eram necessárias, como promover demolições de alto custo para abrir espaços, alargar ruas e avenidas, como foi o caso em Marselha. Mas, para as necessidades da cidade moderna serem supridas, era preciso um plano.

O plano, que ordenaria a construção da cidade, para ser implantando, necessitaria de uma lei que o legitimasse, como ocorria em outros países. Esse modo de assegurar a implantação do plano, do qual Brito citou algumas experiências estrangeiras, é semelhante ao que ocorre atualmente. Segundo MM. Beauquier, Brouardel e Mosny (apud BRITO, 1944b), na Revista Tracé d'Hygiène, outros países já possuíam leis mais práticas e avançadas que a legislação francesa, tais como Bélgica (lei de 1836), Inglaterra (atos de 1872, 1876, 1877, 1878, e a lei 1878), Holanda (1902), Alemanha (1875, 1906 e 1907) e Itália (1865 e 1908). Na França, foi implantada a Loi du 21 avril 1906, segundo a qual, em um prazo de cinco anos, toda comunidade urbana com mais de 10 mil habitantes deveria ter um plano de extensão e embelezamento.

Brito relatou que, desde 1896, ao elaborar os projetos de sanemaneto para as cidades brasileiras - como Vitória, Petrópolis, Paraíba do Sul, Itaocara, Campos, Parahyba do Norte, Santos e Recife - já adotava os princípios dos planos utilizados no contimente europeu, na tentativa de fazer um trabalho mais ou menos completo. Isso era uma iniciativa pessoal, uma vez que, no Brasil, não havia uma lei que regulamentasse o espaço urbano. Em 1916, para a implantação do plano em Santos, Brito disse que esse deveria ser declarado de utilidade pública e ter uma duração de seis a vinte anos, podendo ser necessárias revisões nesse período. Esse mesmo procedimento foi estabelecido pelo Estatuto da Cidade nos artigos 39 e 40, em que o plano diretor deve ser aprovado por lei municipal, é o instrumento básico da política de desenvolvimento e expansão urbana e deve ser revisado, pelo menos, a cada dez anos. Brito trouxe ideias do exterior e aplicou no Brasil de forma pioneira, como avalia Andrade (1992, p. 4), preconizando um urbanismo de cunho sanitarista, mas sem desconsiderar a dimensão estética da cidade, Brito foi, talvez, o principal responsável pela introdução e difusão da urbanística, enquanto uma disciplina autônoma, no Brasil. Justificando e sistematizando, segundo rigorosa racionalidade técnica e econômica, as intervenções do Estado republicano nascente sobre as condições de desenvolvimento urbano, Brito implantará o pla-nejamento urbano na administração de inúmeras cidades brasileiras.

Outros profissionais no Brasil também já tinham a consciência da importância dos planos para as cidades. Brito (1944c, p. 228) relatou que o Dr. Victor da Silva Freire, professor e engenheiro da municipalidade de São Paulo, no que se referia à necessidade de "preparar com antecipação as disposições de uma cidade", comentou na Revista Politécnica que,

nos Estados Unidos, não se cuidou do assunto, têm as cidade pago caro, muito caro, as consequências da sua imprudência. Registra-se uma exceção: Washington. 0 seu plano, confiado a um arquiteto francês, L'Enfant, no final do século XVIII, foi de tal maneira bem concebido que a capital da grande União tem beneficiado, até hoje, das vantagens de um traçado racional.

O plano de Washington apresentado por L'Enfant (Figura 4), em 1871, segundo Brito (1944c, p. 40), "é um eloquente exemplo de aplicação inteligente do traçado geométrico, em xadrez, com longuíssimas avenidas em linha reta, seguindo várias direções, de modo a facilitar as comunicações". Brito considerou a cidade norte-americana "louvável de visitantes distintos e dos homens da arte" e, em Santos e nos demais projetos, aplicou o traçado e elementos desse, como as vias diagonais e os espaços verdes ao longo de eixos e também espalhados pela cidade.

Para mostrar a aplicabilidade e funcionalidade do traçado xadrez com avenidas diagonais e também que não bastava copiá-lo de outras cidades, Brito criticou o plano apresentado por Aarão Reis para a Cidade de Belo Horizonte. Nesse, o traçado das vias não estava aplicado adequadamente devido ao terreno ser acidentado. A melhor solução, conforme propôs Brito (Figura 5), seria uma planta com o traçado sanitário por ele propagado e defendido. Esse seria de acordo com as curvas topográficas do terreno e com avenidas ao longo dos cursos d'água. 


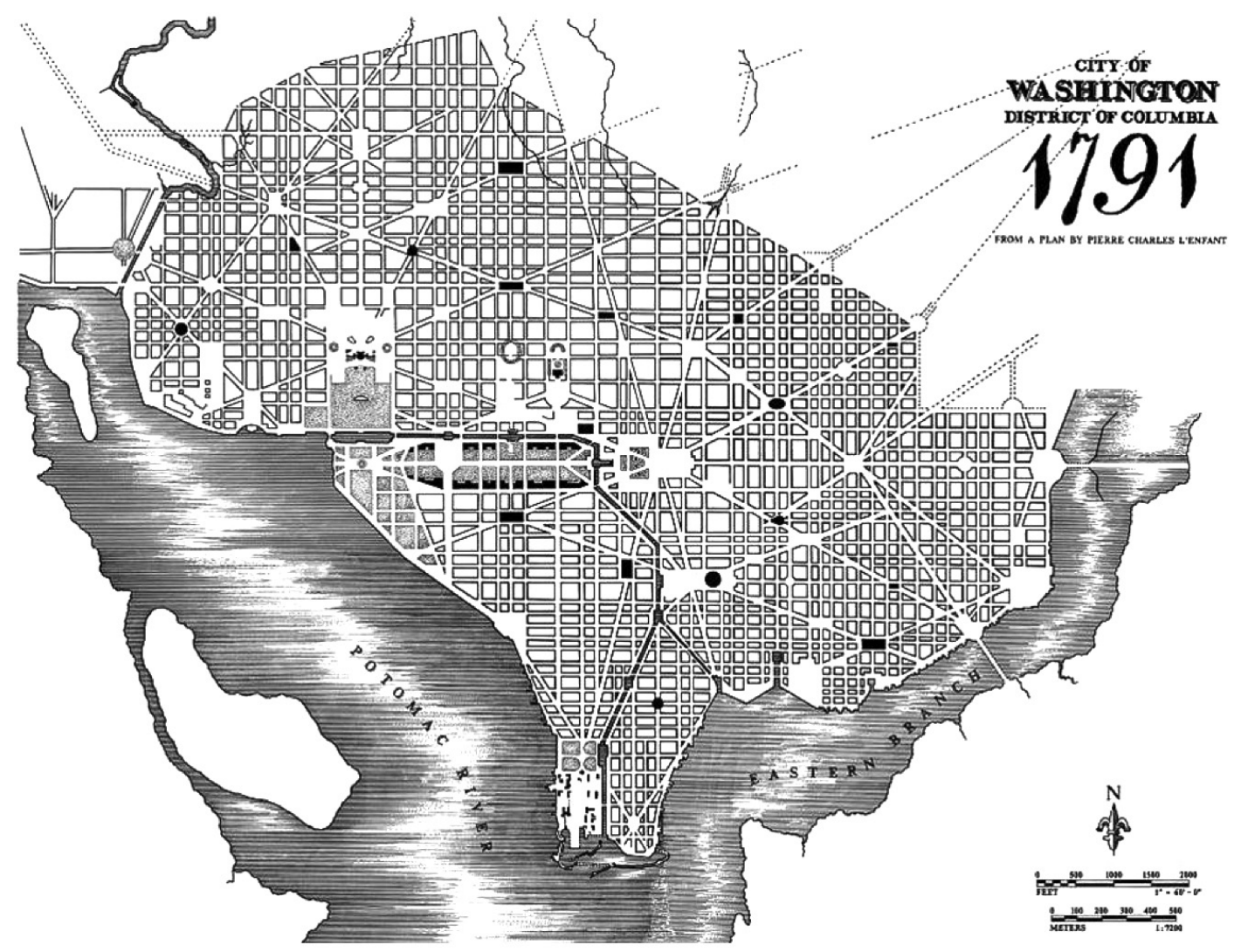

Figuras 4 e 5: A primeira figura é Plano de Washington apresentado por L'Enfant em 1871 com diversas vias em diagonal sobre o traçado ortogonal e a segunda, uma comparação elaborada por Brito (1944b) entre o traçado geométrico previsto para Belo Horizonte por Aarão Reis, desconsiderando a topografia e os cursos d'água, apresentado na Planta A, e o traçado sanitário proposto por Brito na Planta B.

Planta A: Tracado Geometrico

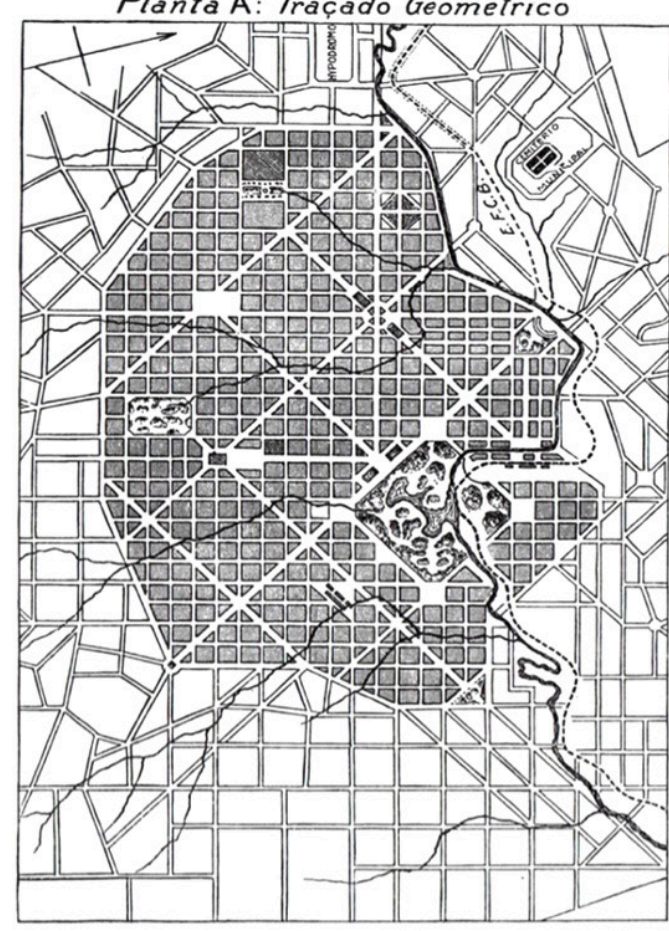

Planta de Bello Horizonte (MINAS)
Planla B: Traçado Sanitario

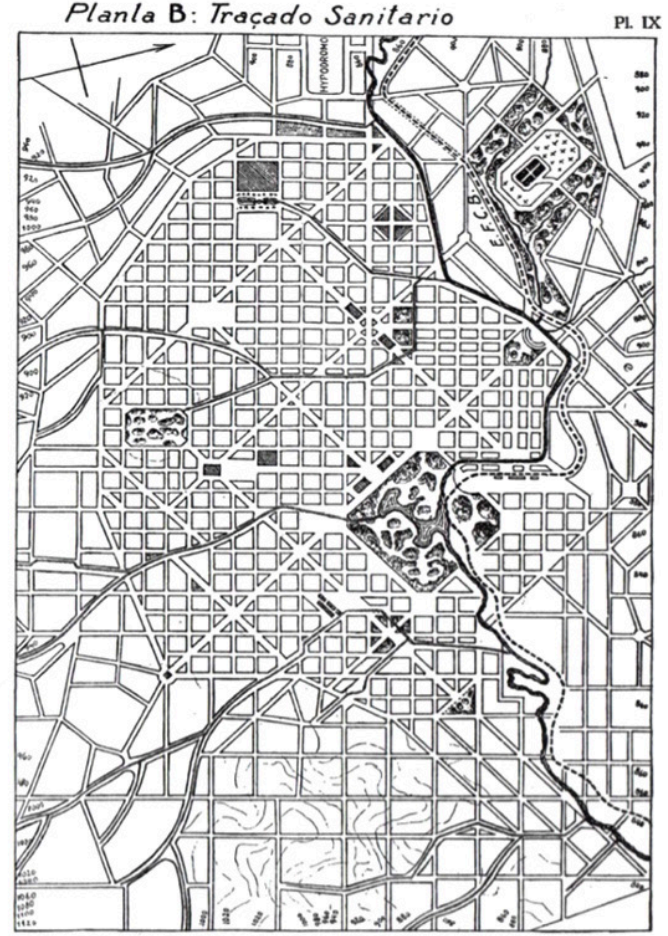

1000 
Em regiões acidentadas, como em Belo Horizonte, a linha sinuosa, alongando as distâncias, deveria ser utilizada devido a sua funcionalidade e não por motivos meramente artísticos. Esse traçado, técnico e estético, ajudaria a reduzir as declividades e o custo das construções as quais atingiriam preços extraordinários se a linha reta fosse adotada. A linha sinuosa também reduziria as velocidades exageradas e os inconvenientes da rede de esgoto pluvial. Do contrário, nas cidades planas, como Washington e Santos,

21 Tradução nossa de "la ligne droite est le chemin le plus court entre deux points".

22 A publicação de Le Corbusier constituiu para Brito a justa compensação dos dissabores da polêmica. Em 1928, no Relatório dos Projetos relativos a Poços de Caldas, Brito (1944c, p. 9) cita as palavras de Le Corbusier a propósito da linha reta: "La rua courbe est le chemin des ânes, la rua droite le chemin des hommes" (Urbanismo, pág. 10). O homem marcha direito: "L'âne zig-zague pour eviter lês Gros cailloux, pour esquiver la pente, por rechercher l'ombre...".

23 Tradução nossa.
[...] os traçados retilíneos mais regulares e mais simples são justamente os mais convenientes para a economia da cidade, isto é, para os estabelecimentos dos serviços de saneamento e de todos os outros serviços municipais; são também os mais convenientes ao policiamento e ao trânsito, desde que sejam traçadas as avenidas diagonais, ou em direções que encurtem as distâncias nas comunicações entre diferentes zonas da cidade (BRITO, 1944c, p. 20).

O traçado geométrico regular era o mais simples e vinha sendo adaptado para todos os países novos. A partir da frase de Brito (1944b, p. 44) "a linha reta é o caminho mais curto entre dois pontos" ${ }^{21}$, comparada com a de Le Corbusier (2009, p. 10) "uma cidade moderna vive praticamente em linha reta [...] o trânsito exige a linha reta", nota-se que aquele já defendia a ideia que, posteriormente, seria propagada por este em 1925, com o livro Urbanisme. Quando Brito (1944c, p. 9) leu o que Le Corbusier ${ }^{22}$ escreveu sobre a linha reta, comentou: "não veio fora de tempo esta estouvada advertência aos nossos urbanistas do pistolet, críticos, sem lastro, das plantas de Belo Horizonte, Santos e outras".

No traçado sanitário que defendeu, Brito combinou o traçado irregular com o regular, este em vias onde era preciso ligar pontos importantes da cidade e aquele em locais de menor trânsito, tirando partido da topografia. Mas ambos sempre orientados para o melhor escoamento das águas.

Quando o terreno é plano, o traçado retilínio, mas não rígido, com avenidas em diagonal ou irradiadas, deve ser adotado, porque facilita muito o traçado sanitário, a circulação, a polícia, a orientação dos pedestres, etc. [...] quando o terreno é acidentado, deve-se preferir o traçado irregular, para concordar com a topografia e as necessidades, fluxo das águas e circulação de veículos com as inclinações adequadas, deve-se considerar, também, o belo efeito pitoresco natural e prever o embelezamento da cidade 23 (BRITO, 1944b, p. 48).

Nos projetos de saneamento e extensão, sempre que possível, Brito conciliou o traçado existente com o sanitário. Esse posicionamento teve origem nas ideias de Sitte, preocupado com a preservação da cidade e contra a política de arrasar quarteirões inteiros, como Haussmann fez em Paris ou Pereira Passos, no Rio de Janeiro. O resultado foi a engenharia sanitária brasileira criada por Brito segundo a Revista D. A. E. (1964). Essa engenharia, aplicada nos planos de saneamento, resultou no urbanismo sanitarista do Eng. Saturnino de Brito que, como avalia Andrade (1994, p. 28), “[...] insere-se no conjunto de operações em grande escala que redefiniram a paisagem urbana de diversas cidades da América do Sul no primeiro quartel do século XX".

A atuação de Brito foi muito mais além do que a simples previsão de um traçado viário para áreas urbanas de expansão ou existentes e indicação de abertura de vielas sanitárias. Esse era um ponto importante, mas que fazia parte de um plano necessário para guiar o crescimento da cidade, o qual dependia de instrumentos legais para garantir sua aplicação. Muitas das ideias sobre o plano, áreas verdes, ocupação dos terrenos, etc. defendidas por Brito em projetos para diversas cidades, estão presentes no livro que citou de M. Eug. Couturaud, Guide pratique pour la Reconstruction, I'Extention, I'Aménagement et I'Embellissement des Villes. Esse foi escrito durante a guerra e contém as proposições de Beauquier, Siegfried, Chenal e M. Cornudet para um projeto de lei.

O livro de M. Eug. Couturaud propunha que todas as cidades com 10 mil habitantes ou mais, ou menores, com crescimento considerável (crescimento quinquenal superior a 10\%); ou se independentemente da população o local apresentasse características pitorescas, artísticas ou históricas teriam o prazo de três anos para estabelecerem um plano de melhoramento, embelezamento e extensão. Esse plano definiria a direção, a largura e a característica das vias novas ou a serem modificadas; determinaria a localização, extensão e posição das casas, praças, jardins públicos, 
áreas de jogos, parques e espaços livres diversos; indicaria as reservas arborizadas ou não, para as funções higiênicas e estéticas, e todas as outras condições relativas e, em particular, a superfície do terreno que poderia ser ocupada pelas construções. A fim de garantir espaços livres na cidade, não seriam mais permitidas novas construções nos limites das vias ou de novos alinhamentos fixados e no interior das quadras. O plano seria implantando através de um decreto ou lei e declarado de utilidade pública (BRITO, 1944b).

Não se sabe em que momento Brito teve acesso a esse livro, mas muitas das propostas que foram implantas pelo engenheiro no Brasil e mais tarde consolidadas pelo Estatuto da Cidade estão muito próximas do proposto nele. Brito (1944b) considerou o livro de M. Couturaud uma oportunidade particular para a França e os países devastados pelas barbáries e, também, muito instrutivo para outros países do mundo, recomendando a leitura para as municipalidades, homens da arte, administração e ao público do Brasil.

Além da preocupação com o saneamento das cidades e com a organização dos espaços urbanos, Brito também se preocupava com o emprego do dinheiro público, defendendo que a cidade deveria ser pensada de modo a não ser preciso tomar decisões onerosas no futuro que poderiam ter sido evitadas no passado, ideia intrínseca ao planejamento. Assim, também defendia que, ao sanear a cidade, o poder público reduziria os gastos com saúde. Para esclarecer, Brito (1943c, p. 23) citou o artigo de uma revista francesa da qual não fez referência:

toda a despesa feita com a higiene é em realidade uma economia; para o indivíduo ou para uma cidade, mais custoso que a moléstia só a morte... E não se esqueçam os intendentes (lá são os maires) $e$ as municipalidades que, se não cuidarem da salubridade, próximo está o momento em que os seus eleitores (que, é bom não esquecer, diz o autor do artigo, são os seus leitores) poderão Ihes pedir contas severas por não terem andado mais apressados e mais resolutamentes no bom caminho.

Cabe destacar ainda que Saturnino de Brito tratou a salubridade da cidade em duas escalas, destacando que a higiene não dependia somente do setor publico, mas também de todas as pessoas. Assim, ele propôs uma abordagem na escala urbana, aquela vista associada ao plano da cidade, e outra na escala local, referente à edificação e seus arredores. A primeira fol o que se viu até aqui e a segunda, indicações para higiene das habitações que escreveu em 1903 e que complementa a primeira, será abordada a seguir.

Os projetos das edificação, segundo Brito, para assegurar que atendessem o que era exigido em lei, deveriam ser analisados pelo poder público. Se o projeto estivesse de acordo com o exigido, seria emitida uma licença para a execução, como ocorre atualmente. Entre as exigências indicadas por Brito (1943c), algumas ainda são mantidas, como o índice de ocupação de até 0,66.

O domicílio, para Brito (1943a), era compreendido pela edificação - a casa - e o pátio. Esse conjunto era o campo de ação doméstica e o ambiente que envolvia e alimentava o indivíduo e a família nos períodos de máxima importância para a sua integridade hígida e moral. Integridade essa que estava ameaçada pelas condições de saneamento, conforto e altos preços dos aluguéis cobrados das famílias com poucas condições econômicas que acabavam por serem obrigadas a se submeter a isso ${ }^{24}$.

A qualidade das habitações, principalmente as de aluguel, foi um sério problema nas cidades brasileiras e europeias, como a Inglaterra e a França na Revolução Industrial e o Rio de Janeiro na Primeira República. Um cômodo, que era parte de uma habitação, era alugado como uma habitação para uma família. Aquele espaço de pequenas dimensões era impróprio para o novo uso e nem tinha instalações sanitárias. A situação piorava quanto mais pessoas houvesse nesse espaço e mais ameaçada ficava a integridade à que Brito se refere, resultando até em um problema social.

A vida exterior é procurada pelo chefe da família desde que Ihe falte conforto no lar; vai gastar com álcool e o jogo as economias que Ihe serviriam para melhor pagar o aluguel da habitação e os gêneros de alimentação. As crianças vão para a rua se exercitarem na maldade, no vício, no vandalismo com que riscam os muros novos, quebram lâmpadas e destroem até as próprias benfeitorias que as favorecem no desamparo doméstico em que vivem (BRITO, 1943a, p. 159). 
25 Muitas edificações possuíam o banheiro mais afastado da rua, onde passava a rede de esgoto. Nos casos em que a inclinação caía ao longo do terreno, o banheiro acabava ficando em cota inferior à da rede coletora de esgoto.
Brito registrou, no Brasil, o mesmo problema habitacional que Benevolo (2005) trouxe de famílias em Glasgow. As condições de higiene eram péssimas, e, em um dos casos descritos por Brito, uma casa velha de $151 \mathrm{~m}^{2}$ foi dividida em 8 compartimentos, sendo um grande e sete pequenos. Em um deles, 0 quarto tinha $2,65 \times 1,35 \mathrm{~m}$ e a sala/cozinha, $2,65 \mathrm{x}$ $3,8 \mathrm{~m}$, não havia janelas e o aluguel era de $10 \$ 000$ mensais. Em outro caso, o espaço media 2,1 x3,98m, contendo sala, cozinha e quarto, não havia janelas, apenas duas portas, a da frente e a dos fundos. Mas não bastava somente evitar essa prática, também eram necessárias regras de construção, hábitos de asseio e boa conduta privada e cívica, juntamente com os serviços de saneamento na cidade.

Os problemas descritos poderiam ser resolvidos por regulamentações abrangendo as escalas urbana e a local. Como se percebe, na cidade atual, o problema foi resolvido ou bem amenizado, como se julgar mais apropriado, através de legislações específicas, como a lei de uso e ocupação do solo e código de obras e edificações. Quando essas foram implementadas, não foi preciso destruir tudo o que não estava de acordo, era só realizar a adaptação, como Brito (1943a. p. 129) defendera: " [...] trata-se de corrigir o que existe e não só de regular novas construções e menos ainda de aceitar a absurda hipótese de tudo arrazar para levantar cidade nova".

A fonte de conhecimento de Brito que Ihe possibilitava chegar a essas propostas era proveniente da Europa e Estados Unidos. As indicações a seguir, muito semelhantes ao que consta atualmente em lei, são propostas por Brito (1943a, p. 124) como "indicações higiotécnicas para projetar, executar e conservar habitações higiênicas e para reformar as casas que existem em más condições sanitárias". Muitas dessas indicações se tornaram de responsabilidade do poder público regulamentar e cobrar do proprietário que deveria as implantar nas edificações. Cabia àquele, por exemplo, limitar o aproveitamento da superfície do terreno e a altura da edificação e fixar o mínimo de área de pátio necessária; enquanto a este, construir uma casa salubre, buscar e preservar bons hábitos de higiene.

Era preciso uma série de cuidados, até ao construir uma casa, uma vez que essa acabaria por influenciar nas questões de salubridade do quarteirão. Antes de iniciar a construção, Brito (1943a) defendeu que era preciso conhecer o tipo de solo, as condições e dimensões do lote para saber como iniciar a edificação e que medidas tomar no projeto para evitar ou atenuar situações inconvenientes, incluindo a insalubridade. $\mathrm{O}$ entorno do lote era muito importante, dependendo das edificações vizinhas e a ocupação do espaço, no caso se não houvesse recuos, seria preciso buscar outros artifícios para favorecer a salubridade. Nos lotes de dimensões reduzidas em que não fosse possível fazer o recuo, era preciso abrir amplos poços de luz para ventilação e iluminação.

Os estudos no exterior, comentados por Brito (1943a), mostravam a importância dos recuos e pátios para a higiene. O Dr. Carraroli, médico italiano, recomendava afastamento lateral mínimo de cinco metros entre prédios ou, preferencialmente, de no mínimo igual à altura da edificação. Se nenhum desses valores fosse possível, era melhor simplesmente não recuar para evitar outros problemas, como áreas mal ventiladas e úmidas.

Frente à necessidade de garantir o recuo lateral, os pátios com acesso independente das residências e resolver o problema dos casos da rede de esgoto estar em cota superior à do banheiro da edificação ${ }^{25}$, Brito propôs a viela sanitária. Essa modalidade de via urbana facilitaria a limpeza do lote e a implantação e manutenção da infraestrutura urbana, como a rede de esgoto, de abastecimento de água e de luz. Nessa via, seria permitido somente o trânsito de veículos destinados à limpeza e os de tração humana, para não danificar a pavimentação que poderia ser de valor e qualidade inferiores à das ruas. Com isso, não seria preciso se preocupar com os frequentes danos à pavimentação das ruas para resolver os problemas de manutenção da infraestrutura que estaria na viela. Brito confere maior importância à implantação das vielas que aos alargamentos viários de forma sistemática.

As vielas teriam largura de quatro a cinco metros e, para não se tornarem insalubres, era preciso limitar a altura das dependências que atingissem o seu alinhamento ou dos muros. Esses deveriam ser de alvenaria até a altura de um metro e depois receberiam gradil ou tela de arame sem fechamento vegetal, para garantir a iluminação, insolação e a ventilação do interior dos quarteirões (Figura 6). Nos estudos, Brito mostra o traçado das vielas que devem ser conforme as condições possíveis e mais econômicas, desde que não sejam curvas e nem possuam mais de dois alinhamentos. 
26 Brito também indica que o uso de elevadores pode ser generalizado em edificações com mais de dois pavimentos.

27 Nem todos os cômodos de uma habitação mencionados por Brito serão comentados por não possuírem informações relevantes para esse trabalho, como locais de trabalho e sala de jantar

Figura 6: Instalação dos esgotos domiciliares e banheiro em corte e em planta, Fig. $1,2,3$ e 4, e relação entre a parte de serviço de uma edificação, banheiro, pátio e viela sanitária no desenho identificado como Fig. 5. Fonte: Brito (1943a)
A escada, embora muito útil nas edificações, ao mesmo tempo, é perigosa e pode ser desconfortável. Para diminuir a fadiga dos degraus ${ }^{26}$ e assegurar a segurança do usuário, Brito indica degraus de 15 a $18 \mathrm{~cm}$ de altura por 30 a $40 \mathrm{~cm}$ de base, com patamares de descanso. Também salienta a importância do corrimão e de manter os degraus bem iluminados e sempre limpos, sendo os de pedra e ferro mais vantajosos em casos de incêndio. Nas normas de Saídas de emergência em edifícios (NBR 9077/1993) e de Acessibilidade a edificações, mobiliário, espaços e equipamentos urbanos (NBR 9050/2004), elaboradas pela Associação Brasileira de Normas Técnicas (ABNT), constam indicações semelhantes às já indicadas por Brito. "Os degraus devem: a) ter altura $\mathrm{h}[\ldots]$ compreendida entre $16,0 \mathrm{~cm}$ e $18,0 \mathrm{~cm}$, com tolerância de $0,05 \mathrm{~cm}$; b) ter largura b [...] dimensionada pela fórmula de Blondel: $63 \mathrm{~cm} \leq(2 \mathrm{~h}+\mathrm{b}) \leq 64 \mathrm{~cm} "$ (NBR 9077/1993, p. 9). Considerando a base do degrau o piso e a altura o espelho, "as dimensões dos pisos e espelhos devem ser constantes em toda a escada, atendendo às seguintes condições: a) pisos (p): $0,28 m<p$ $<0,32 \mathrm{~m}$; b) espelhos (e) $0,16 \mathrm{~m}<\mathrm{e}<0,18 \mathrm{~m}$; c) $0,63 \mathrm{~m}<\mathrm{p}+2 \mathrm{e}<0,65 \mathrm{~m}$ " (NBR 9050/2004, p. 45).

O médico alemão Dr. Erwin Esmarch elaborou um trabalho relativo aos cômodos de uma casa. Sobre esse trabalho Brito fez referência e desenvolveu um semelhante, listando as peças de uma habitação com as respectivas finalidades e cuidados que mereciam. Na residência, as peças mais importantes eram o banheiro e a cozinha, onde o alimento consumido é preparado e o mal pode ser levado ao organismo ${ }^{27}$. Muitas das medidas de higiene indicadas para essas duas peças ainda estão presentes em códigos de edificações atuais e leis sanitárias para facilitar a limpeza, como paredes revestidas de material impermeável até a altura de 1,5 a $2 \mathrm{~m}$. No caso do banheiro, para garantir uma boa ventilação, Brito indicou que fosse como um apêndice da edificação e tivesse mais de uma janela (Figura 6).

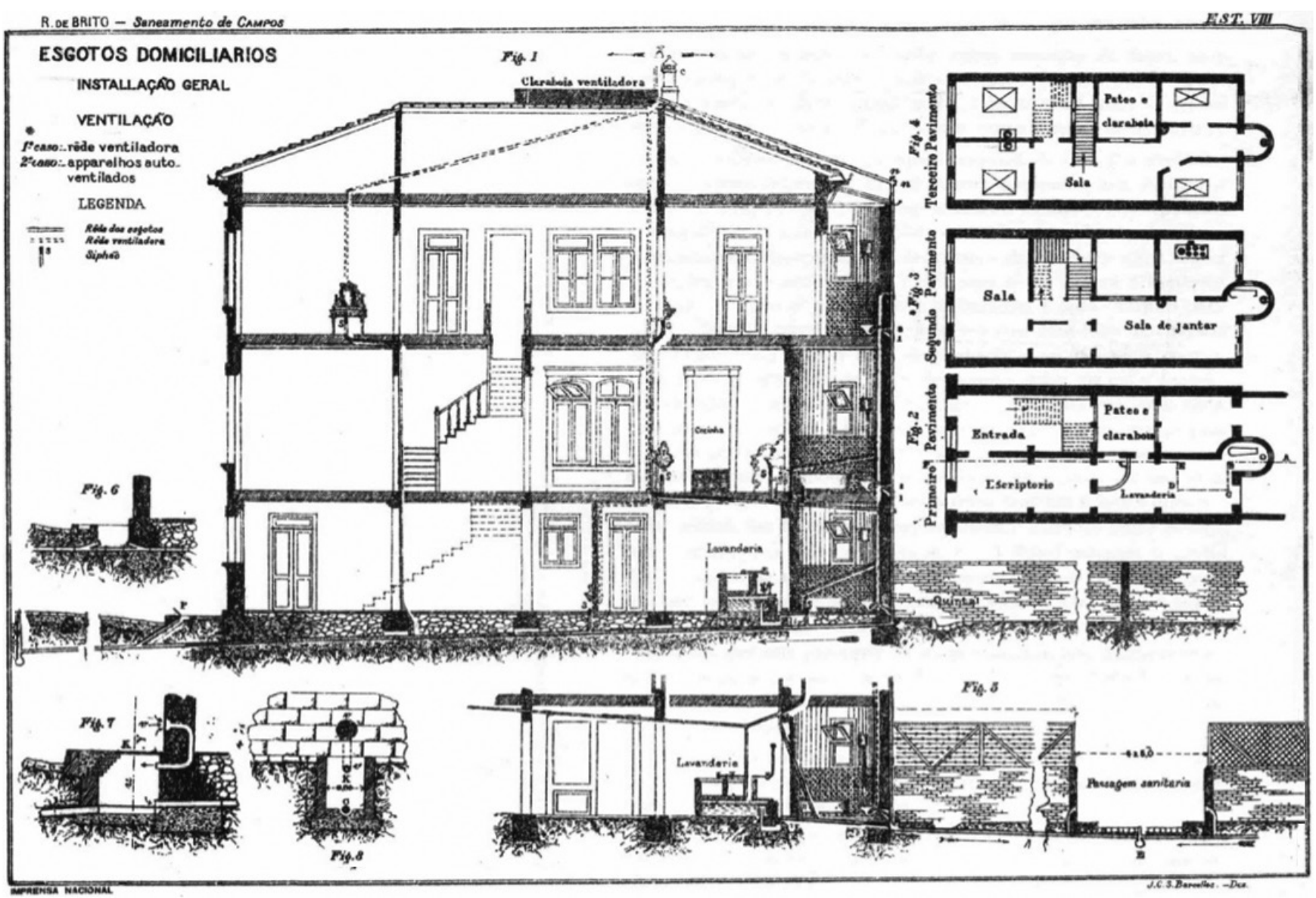


28 Propôs uma cidade autossuficiente onde as pessoas trabalhariam no campo e na indústria. A proposta foi apresentada ao governo inglês e às autoridades centrais, que não demonstraram interesse. Owen tentou pôr ela em prática na América e comprou um terreno em 1825 em Indiana. Ele acabou adaptando suas ideias à aldeia existente e o resultado não foi o esperado para uma comunidade autossuficiente. Mesmo assim, New Harmony virou o principal centro científico e educativo do Oeste e ofereceu melhores condições de moradia e saúde às pessoas.

29 Acreditava que as paixões produziam as relações entre os homens. Propôs uma estruturação social em falanges e não em família.

Figura 7: Estudo de habitações populares salubres e econômicas. Fonte: Brito (1943a)
Uma prática muito comum naquela época era fazer o banheiro nos vãos das escadas e, também, as prefeituras aprovarem plantas de hotéis e restaurantes com paredes de banheiros que nem chegavam até o teto e sem abertura para o exterior, conforme relata Brito (1943a). Poucos eram os estudos sobre os empregos desses preceitos no Brasil. No Rio de Janeiro, preocupavam-se mais "[...] com as desinfecções e com o matar mosquitos do que com o estudo do aparelho sanitário das habitações, procurando efetivamente conhecer, para que se corrija, os defeitos prediais, originários de quase todos os sintomas mórbidos" (BRITO, 1943a, p. 150).

Do mesmo modo que o industrial inglês Robert Owen ${ }^{28}$ e o filósofo francês Charles Fourier ${ }^{29}$ se preocuparam com as habitações operárias, Brito, embora com uma preocupação social mais reduzida em relação aos dois, projetou habitações populares salubres e econômicas. Esse defendia a necessidade de dar habitações salubres aos operários, tirandoos dos miseráveis abrigos em que muitos viviam infelizes. Como exemplo citou diversas habitações operárias industriais, como a vila da Krupp em Essen, na Alemanhã, e fez referência às medidas que estavam sendo adotadas na Inglaterra, como a

[...] moderna cruzada pela formação do lar operário, porquanto o benefício que se faz às famílias pobres se constitue em garantias para a coletividade, quer no ponto de vista estritamente higiênico, desaparecendo tantos focos de insalubridade, quer na ordem social e moral, pela elevação correlata dos sentimentos e da conduta do proletariado (BRITO, 1943a, p. 152).

A proposta de Brito era de edificações com as laterais recuadas a partir do segundo pavimento, para aumentar a ventilação e iluminação dos pavimentos superiores. A organização das habitações seria em módulos de $14 \times 5 \mathrm{~m}\left(70 \mathrm{~m}^{2}\right)$, medidos internamente, mais o banheiro nos fundos como apêndice de $3 m^{2}$. Cada grupo seria composto de dois ou três módulos (Figura 7).

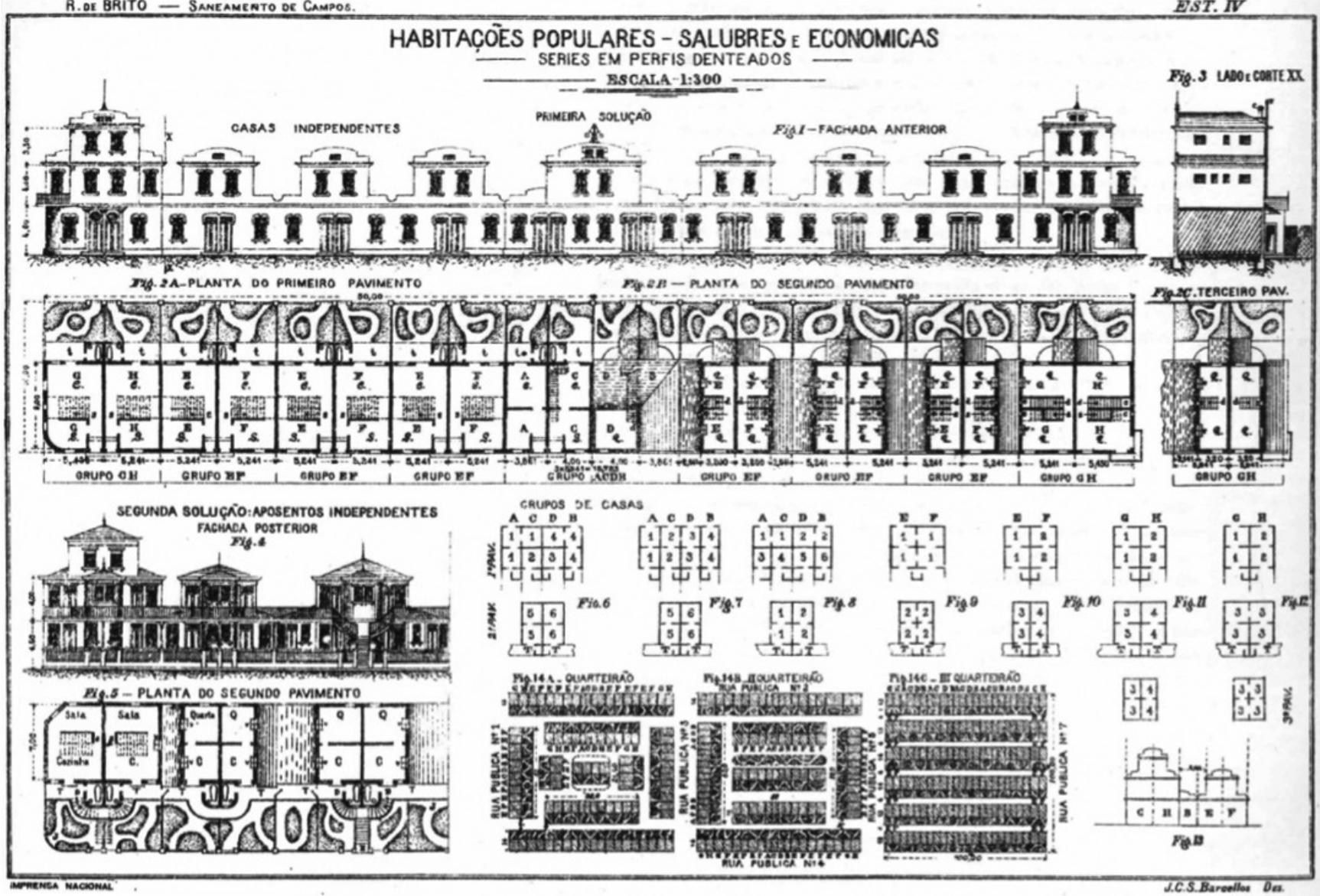


As quatro tipologias diferentes poderiam ser agrupadas conforme desejado, mas a composição deveria ocorrer de modo que uma não prejudicasse a ventilação e iluminação da vizinha, sendo necessário fazer a intercalação do tipo GH com os demais. Na composição do quarteirão, as séries de casas e jardins se separavam entre si pelas ruas internas com largura de $7 \mathrm{~m}$ ou vielas sanitárias de 4 a $5 \mathrm{~m}$ de largura. Para cada tipologia, o engenheiro desenvolveu uma série de tabelas e estudos mostrando a viabilidade econômica. Entre elas, a que se destaca é a tabela com as áreas, custos e valores dos aluguéis (BRITO, 1943a, p. 167).

\section{Concluindo}

Saturnino de Brito sempre valorizou a atuação profissional no campo da arquitetura, defendendo que

com o mesmo material e o mesmo dinheiro, mal aplicados por incompetentes "mestre dobras", o bom arquiteto executará uma habitação correta: bonita e resistente. [...] não é a ornamentação abundante e pretenciosa que dá estilo e beleza à obra e nem a superfície ocupada; as linhas corretas, as proporções guardadas entre os elementos arquitetônicos dão à fachada a necessária beleza, e, com economia de espaço e de capital, a boa distribuição no plano trás à casa o desejado conforto, a segurança higiênica (BRITO, 1943a, p. 132).

No campo do urbanismo, Brito (1944b, p. 174) enviou uma carta ao Sr. Don Horacio Acosta y Lara, Presidente do Congresso Pan-Americano de Arquitetos, citando a publicação do seu trabalho em francês e comentando os profissionais que teriam habilitações para trabalhar com urbanismo.

O "urbanismo" ainda não constitue uma arte reservada a especialistas; desse fato resulta: $1^{\circ}$ que tem sido e continua a ser praticado, em todos os países, por engenheiros civis, eletricistas, arquitetos, e mesmo por agrimensores e pelos "políticos" que dirigem os negócios municipais das pequenas cidades, e decretam a abertura das ruas, a formação das praças, etc.; $2^{\circ}$ que o engenheiro sanitário, quando tenha de organizar os planos de saneamento, para os fazer completos e satisfatórios, prevendo o futuro, evitando erros evitáveis, deve começar pelos projetos de expansão, modificando os que existam defeituosos no ponto de vista das utilidades que o preocupam. Do contrário o seu projeto será defeituoso. Discuti o assunto no livro Le Tracé Sanitaire des Villes e ele merece a atenção dos Arquitetos porque, realmente, da sua classe mais facilmente devem sair os verdadeiros "urbanistas", desde que saibam conciliar a prudência do senso prático com as aspirações do esteta, as utilidades e o belo efeito evitando os exageros da fantasia.

Enquanto não existirem urbanistas com a plena competência para resolverem as questões complexas relativas ao traçado das cidades, é preciso que, nos casos comuns da prática, os projetos sejam organizados por engenheiros sanitários ou que sobre os mesmo sejam estes consultados; nos casos especiais (grandes cidades, cidades jardim) é indispensável o concurso do senso estético.

Para Brito, não havia como pensar isoladamente no saneamento de uma cidade, era preciso realizar um planejamento urbano, mesmo que incipiente se comparado com a abrangência e magnitude que esse tem atualmente. Era preciso pensar a cidade como um todo, saneamento, áreas existentes e a serem ocupadas, traçado e legislações. Ao justificar suas decisões técnicas, o engenheiro promoveu a circulação de ideias principalmente entre Brasil e Europa, com base nos Annales des Ponts et Chaussées, o livro Distributions d'eau de Debauve e Imbeaux, as revistas Eng. Record, Eng. News e La Technique Sanitaire, da qual possuía a assinatura e que, além de questões técnicas de saneamento, trazia discussões sobre o planejamento das cidades. Além disso, Brito trocava cartas com Edm. Imbeaux, Ingénieur en Chef des Ponts et Chaussées e Directeur des Travaux de la Ville de Nancy. O sobrinho de Brito conta que os dois se corresponderam por, pelo menos, trinta anos e, uma vez, o engenheiro francês foi a Recife admirar os trabalhos de saneamento. Como apresentado, o envolvimento de Brito com a Planta de Santos foi de extrema importância para divulgação de sua atuação no campo do urbanismo, o que o levou a ser convidado para participar da Exposition de la Cité Reconstituée, realizada em Paris, em 1916 e, ainda em junho de 1909, enquanto estava em Santos, recebeu o convite do Governador do Estado de Pernambuco para dirigir a Comissão de Saneamento do Estado que seria criada com o início das obras de saneamento em Recife. 
Brito mostrou, de forma prática e teórica, as medidas necessárias para garantir o saneamento das cidades e das habitações, juntamente com as responsabilidades por parte do poder público e de cada pessoa. As ideias que defendia ficaram muito conhecidas, o que o levou a ser chamado para elaborar projetos de saneamento para diversas cidades do Brasil, onde, a partir do saneamento, colaborou para o início o processo de planejamento urbano.

Além da importância que teve no território nacional, Brito também ficou conhecido na Europa por suas publicações. Carlos Rodrigues de Brito, sobrinho do engenheiro, em Notas Biográficas, escreveu sobre a vida de Brito, inclusive sobre uma experiência que teve em Londres. Este relato é muito importante porque responde ao questionamento levantado sobre se Brito chegara a ir alguma vez à Europa.

Um episódio dessa viagem foi contado pelo "Diário da Manhã", de Aracajú, após sua morte, quando se soube melhor da sua vida. Ei-lo: "Em visita de estudo e observação a essa grande metrópole (Londres) europeia, o Dr. Saturnino de Brito, que primava pelos seus hábitos de modéstia e cortesia, entrou numa livraria dalí para adquirir as últimas novidades sobre engenharia sanitária, e imaginese qual não tenha sido a sua surpresa, quando o livreiro Ihe disse que o que havia de mais novo e melhor no assunto, pela procura que estava sendo, era um trabalho de um brasileiro, um trabalho do Dr. Saturnino de Brito. Conta-se que o eminente brasileiro nem mesmo assim se deu a conhecer" (BRITO, C. R. de, 1964, p. 16).

A atuação de Brito no campo do urbanismo moldou o processo de planejamento urbano no País. Com Brito, inicia-se um modo mais abrangente de ver e tratar o espaço urbano, o que resulta na necessidade de um plano geral para prever e gerenciar a expansão da cidade, as formas ideais de traçado urbano de acordo com as necessidades, artístico ou xadrez, o urbanismo sanitarista e as medidas legais para estruturar e implantar o plano.

O conhecimento que tinha da engenharia sanitária, da versão francesa do livro de Sitte com princípios de Martin, contato com as obras de Beauquier, Siegfried, Chenal e M. Cornudet e acontecimentos da Europa marcaram a discussão sobre o caso de Santos, o livro Notes sur le tracé sanitaire des villese a forma como atuava e pensava a cidade. Nesse livro, Brito lançou uma teoria de como traçar e planejar a cidade, definindo as necessidades da cidade moderna e a ideia de planejamento, pensando a cidade do ponto de vista técnico e artístico.

O único objetivo de todo o trabalho de Brito era tornar as cidades salubres. Para atingi-lo, o engenheiro desenvolveu um grande trabalho prático e teórico e promoveu uma importante circulação de ideias entre Brasil e Europa principalmente. A importância e a repercussão disso também foi enorme, ao ponto que seus projetos para as cidades brasileiras e inclusive os problemas que teve na implantação deles - como em Santos - resultaram na teoria do traçado sanitário, premiada e publicada na França como Notes sur le tracé sanitaire des Villes.

\section{Referências bibliográficas}

ANDRADE, Carlos Roberto Monteiro de. A peste e o plano: o urbanismo sanitarista do Engenheiro Saturnino de Brito. São Paulo: USP, 1992. Dissertação (Mestrado em Estruturas Ambientais Urbanas), Faculdade de Arquitetura e Urbanismo, Universidade de São Paulo.

Camillo Sitte, Camille Martin e Saturnino de Brito: traduções e transferências de idéias urbanísticas. In: Origens das políticas urbanas modernas: Europa e América Latina, empréstimos e traduções. Rio de Janeiro: IPPUR/CSU, 1994

BENEVOLO, Leonardo. História da cidade. São Paulo: Perspectiva, 2005.

BERGERON, M. J. Présentation du Livre de M. Rodiguez de Brito. Technique Sanitaire, Paris, n. 10, ano XI, p. 265-6, octobre/1916.

BERMAN, Marshall. Tudo que é sólido desmancha no ar: a aventura da modernidade. Tradução de Carlos Felipe Moisés, Ana Maria L. Ioriatti e Marcelo Macca. São Paulo: Companhia da Letras, 2007.

BRASIL. Lei n. 10.257/2001, de 10 de julho de 2001 Estatuto da Cidade. Regulamenta os arts. 182 e 183 da Constituição Federal, estabelece diretrizes gerais da política urbana e dá outras providências.

BRITO, Carlos Rodrigues de. Notas biográficas. D. A. E.: revista do Departamento de águas e esgotos de São Paulo da Secretaria dos Serviços e Obras Públicas. Engenheiro Francisco Saturnino Rodrigues de Brito: número especial em homenagem ao patrono da engenharia sanitária brasileira. São Paulo: [S.ed.], p.07-20, ano XXV, 1964.

BRITO, Saturnino de. Obras Completas de Saturnino de Brito. Rio de Janeiro: Imprensa Nacional, 1943a. v. VI.

BRITO, Saturnino de. Obras Completas de Saturnino de Brito. Rio de Janeiro: Imprensa Nacional, 1943b. v. VII.

BRITO, Saturnino de. Obras Completas de Saturnino de Brito. Rio de Janeiro: Imprensa Nacional, 1943c. v. X. 
BRITO, Saturnino de. Obras Completas de Saturnino de Brito. Rio de Janeiro: Imprensa Nacional, 1944a. v. XVIII.

Obras Completas de Saturnino de Brito. Rio de Janeiro: Imprensa Nacional, 1944b. v. XX.

Obras Completas de Saturnino de Brito. Rio de Janeiro: Imprensa Nacional, 1944c. v. XXI.

COLLINS, George. Camillo Sitte and the Birth of Modern City Planning. London: Phaidon Press, 2006.

D. A. E.: revista do Departamento de águas e esgotos de São Paulo da Secretaria dos Serviços e Obras Públicas. Engenheiro Francisco Saturnino Rodrigues de Brito: número especial em homenagem ao patrono da engenharia sanitária brasileira. São Paulo: [S.ed.], p.07-20, ano XXV, 1964

E CORBUSIER. Urbanismo Traduzido por Maria Ermantina Galvão. 3.ed. São Paulo: editora WMF Martins Fontes, 2009. Traduzido de: Urbanisme.
NBR 9077/1993, de maio de 1993. Saídas de emergência em edifícios.

NBR 9050/2004, de 31 de maio de 2004. Acessibilidade à edificações, mobiliário, espaços e equipamentos urbanos.

PICON, Antoine. Racionalidade técnica e utopia: a gênese da haussmannização. In SALGUEIRO, Heliana Angotti [org.]. Cidades capitais do Século XIX: racionalidade, cosmopolismo e transferência de modelos. São Paulo: Editora da Universidade de São Paulo, 2001.

ROLNIK, Raquel. Impacto da aplicação de novos instrumentos em cidades do estado de São Paulo. In Revista Brasileira de Estudos Urbanos e Regionais. A. $1 \mathrm{n}^{\circ}$ 2. Recife: Norma Lacerda, 1999.

SOUZA, Celia Ferraz de. Plano Geral de Melhoramentos de Porto Alegre, o plano que orientou a modernização da cidade. Porto Alegre: Armazém Digital, 2a.ed., 2010 